\title{
Russian Market of Agricultural Equipment: Challenges and Opportunities
}

\author{
Irina A. Morozova ${ }^{1} \&$ Tatiana N. Litvinova ${ }^{2}$ \\ ${ }^{1}$ Volgograd State Technical University, Volgograd, Russia \\ ${ }^{2}$ Volgograd State Agrarian University, Volgograd, Russia \\ Correspondence: Irina A. Morozova, Volgograd State Technical University, Lenin Avenue, 28, Volgograd, \\ 400005, Russia. Tel: 79-05-334-9998 E-mail: morozovaira@list.ru
}

Received: August 15, 2014 Accepted: September 15, 2014 Online Published: November 14, 2014

doi:10.5539/ass.v10n23p68

URL: http://dx.doi.org/10.5539/ass.v10n23p68

\begin{abstract}
Agricultural equipment manufacturing is one of the most strategically important sectors of national economy providing to a large extent food security of the country. The modern society faces food problems, therefore problems of agricultural economy development, as well as problems of manufacturing modern agricultural equipment competitive with foreign analogues; hence, the issue of studying the Russian market of agricultural equipment is not only of current interest but as well of strategic importance. The article analyzes the condition of the Russian agricultural equipment market, which has been critically monopolized today. At the same time, negative tendencies fully formed in its system can exert negative and significant influence on the national food security (when the customers have no appropriate market choice of agricultural equipment; with vigorous price manipulations of the sellers; information failure as well as non-equal terms of market behavior for different producers). The authors believe that these tendencies cannot be resolved without active and cautious interference of the state specifically into the processes of developing highly competitive business environment. Besides, it is necessary to work out the concept of accompanying infrastructural developments while manufacturing and marketing the agricultural equipment; that will optimize the opportunities of the domestic manufacturers.
\end{abstract}

Keywords: agricultural equipment market, competitiveness, entrepreneurial business, market monopolization, symbiotic enterprises

\section{Introduction}

Functions of agricultural equipment market as institutional setting include first of all increasing GDP, meeting the demand for agricultural equipment within the country, providing employment opportunities for labor work force, preserving the competitive advantages of agricultural equipment producers within the country. We can say as follows that these functions practically fail to be fulfilled.

Today the institution of the Russian agricultural equipment market is dysfunctional due to polarity of the positions of the key participants, absence of coherent interests both among the producers themselves and among the producers and consumers. Dysfunctionality improvement is possible only by taking into account the interests of the consumers (for the present the absence of infrastructure demonstrates only ignoring their interests); the participant who will be the first to start conducting the turn will dominate; but as a whole, this institution may win only ending the "war" in the context of closer cooperation. Infrastructure of market relations between domestic producers is weaker than that of foreign ones, that is why not only today the actions of foreign entrepreneurs can be characterized by greater efficiency, but due to it, in future the latter will have greater potential for developing (Rodrigues et. al., 2007).

In general, the society faces the forthcoming food problems; and even today in our country, developing the agricultural industry and therefore manufacturing the agricultural equipment capable of competing with foreign analogues are of strategic importance. That is why the issue of studying the Russian market of agricultural equipment is not only of current interest but as well of strategic significance.

\section{Approaches to Studying the Russian Market of Agricultural Equipment}

To research the Russian market of agricultural equipment let us combine two approaches. The first approach is based on the traditional analysis. So let us dwell on the peculiarities of the demand (factors determining its 
dynamics on the particular market, satisfaction level, degree and nature of elasticity); peculiarities of the supply (quantity of the manufacturing enterprises supplying the agricultural equipment in our country, their resources and capabilities, scientific and technical potential, workload of capacities, nature of competition between them, relations with the government).

The second approach is based on the analysis of transformations rate and degree in the context of the particular institution, formalization level to determine control degree (the more nonformal component there is, the more control there should be), references of the institution area (indices of polarity and complementary nature typified and reproduced in the context of its institutions, availability of substitutes or servitudes) (Frolov, 2008).

Having combined these two approaches let us study the character of demand and supply from the traditional point of view emphasizing probable dynamics, with analyzing the infrastructural elements as processes ensuring security of the particular market functioning (preventing destructive shocks) as well as market functionality in the context of the country. After analyzing the market within the given limits, we will be able to estimate not only its functionality but also availability of adjustment conditions taking into account social and economic interests of the country.

At first, it is necessary to define the market nature in the industry from the point of view of competition, because it gives us the understanding of the dominant characteristics of the market main participants' behavior. It is common knowledge that the higher degree of market monopolization there is, the more the market becomes dependent on the actions of certain determining groups, and the less it can be forecast in terms of application of market regularities and rules.

Let us analyze the monopolization degree using as a guide the indirect measures of the enterprise market power, applied in the theory of branch markets (Herfindahl - Hirschman indices, concentration on three largest companies according to Hall and Tideman, relative concentration according to five largest companies as well as index of actual entropy of market shares).

The Russian agricultural equipment market includes in terms of supply three substantial groups:

1. Russian manufactures.

2. Foreign manufactures.

3. Symbiotic enterprises manufacturing agricultural equipment.

The scientists traditionally analyze the Russian manufactures in the context of the Big Three:

1. Concern "Tractor Plants" including eleven largest multiprofile mechanical engineering plants and two research organizations (non-profit partnership).

2. Industrial Union "New Commonwealth" organized on the basis of Combine Plant Rostselmash Ltd and Company "Klever" (the union unites twenty enterprises located in the Rostov and Volgograd Regions, Moscow, Kazakhstan and Ukraine).

3. Company "Kirovsky Plant" involving fifteen multiprofile enterprises including St. Petersburg Tractor Plant and "Kirovec-Landtehnik" (joint Russian and German enterprise) (Morozova \& Litvinova, 2013).

These manufacturers provide $95 \%$ of the aggregated Russian output of industrial and agricultural mechanical engineering in a symbiotic manner with Chelyabinsk Tractor Plant. Nevertheless, we find it difficult to characterize them as exclusively domestic manufacturers because they include coalition enterprises.

It should be noted that so called "link with science" is critically weak, not providing enough innovative component of the agricultural equipment manufacturing process. New developments of the former Agromashholding - Enisey-960 and caterpillar tractor BT - 200 Grain Harvester Vector - are considered as prospective competitiveness with foreign combines (developments of Combine Plant Rostselmash Ltd), but there are statements that most progressively developing agricultural regions, for example, the Beloglizensky Region, refuse to use caterpillar vehicles replacing them with more ultimate models. The industry develops slowly progressive directions (i.e. machinery conversion to natural-gas-based motor fuel, resource-saving technology and biofuel application). We would be able to receive new technologies within the framework of associations with foreign manufacturers; but during too long period, it was more profitable for foreigners to import their equipment free of customs duties, with VAT recovery, than to assemble it at the premises of our enterprises (Snelder et al., 2009).

Today the availability of specialists in the industry is not satisfactory; and the quality of the specialists is low. Average salary in agricultural industry does not exceed 10000 rubles per month. During the crisis, it was 
practically impossible to ensure financial provision for external participants of the market; and the infrastructural components, which started to develop, are being destroyed now.

Marketing infrastructure assumes organizing dealer network, establishing contacts with companies studying the peculiarities of potential customers and possibilities of attracting them, providing customer database as well as relation systems with leasing companies. These components are indeed not developed. It is demonstrated both by growing index of unsatisfied demand for agricultural equipment, and policy of positioning as demonstrating one's own competitive advantages to the customers (Snelder et al., 2008).

In recent years, almost all kinds of agricultural equipment are inclined to decrease steadily (Table 1,2).

Table 1. Fleet of equipment at agricultural organizations (at the end of year, thousand pieces)

\begin{tabular}{|c|c|c|c|c|c|c|c|c|c|c|}
\hline & \multirow{2}{*}{1992} & \multirow{2}{*}{1995} & \multirow{2}{*}{2000} & \multirow{2}{*}{2005} & \multirow{2}{*}{2008} & \multirow{2}{*}{2010} & \multirow{2}{*}{2011} & \multirow{2}{*}{2012} & \multicolumn{2}{|c|}{2012 in $\%$ by } \\
\hline & & & & & & & & & 2008 & 2011 \\
\hline Tractors & 1290.7 & 1052.1 & 746.7 & 480.3 & 364.4 & 310.3 & 292.6 & 276.2 & 75.8 & 94.3 \\
\hline Ploughs & 460.3 & 368.3 & 237.6 & 148.8 & 106.3 & 87.7 & 81.9 & 76.3 & 71.8 & 93.1 \\
\hline Cultivators & 541.6 & 403.5 & 260.1 & 175.5 & 138.4 & 119.8 & 114.1 & 108.7 & 78.5 & 95.2 \\
\hline Seeding machines & 582.8 & 457.5 & 314.9 & 218.9 & 159 & 134 & 123.6 & 115.4 & 72.6 & 93.3 \\
\hline \multicolumn{11}{|l|}{ Combines: } \\
\hline Grain harvesters & 370.8 & 291.8 & 198.7 & 129.2 & 95.9 & 80.7 & 76.6 & 72.3 & 75.4 & 94.4 \\
\hline Corn combines & 10.0 & 7.4 & 4.4 & 2.2 & 1.3 & 1.1 & 0.9 & 0.8 & 61.5 & 88.9 \\
\hline Forage harvesters & 120.1 & 94.1 & 59.6 & 33.4 & 1.1 & 0.7 & 0.7 & 0.6 & 54.5 & 85.7 \\
\hline Potato harvesters & 30.9 & 20.6 & 10.0 & 4.5 & 3.4 & 2.9 & 2.8 & 2.7 & 79.4 & 96.4 \\
\hline Flax combines & 8.5 & 5.9 & 3.2 & 1.8 & 24 & 20 & 18.9 & 17.6 & 73.3 & 93.1 \\
\hline $\begin{array}{l}\text { beet harvesters } \\
\text { (without haulm gatherers) }\end{array}$ & 24.7 & 19.7 & 12.5 & 7.2 & 4.2 & 3.2 & 3.1 & 2.8 & 66.7 & 90.3 \\
\hline Mowing machines & 208.2 & 161.6 & 98.4 & 63.9 & 49.2 & 41.3 & 39.3 & 37.5 & 76.2 & 95.4 \\
\hline Balers & 79.5 & 65.1 & 44.0 & 32.4 & 27.2 & 24.1 & 24.2 & 23.7 & 87.1 & 97.9 \\
\hline Reaping-machines & 218.7 & 152.2 & 85.2 & 46.9 & 33.3 & 27 & 25.2 & 23.6 & 79.9 & 87.4 \\
\hline $\begin{array}{l}\text { Sprinkling-machines andwater carts; } \\
\text { sprinkler installations and drenchers }\end{array}$ & 69.5 & 46.3 & 19.2 & 8.6 & 6 & 5.4 & 5.3 & 5.2 & 86.7 & 98.1 \\
\hline
\end{tabular}

Source: compiled by the authors according to the data provided by Dzotsenidze, Ipatov (2008), Didmanidze, Yesenovsky-Lashkov, Pilschikov (2005), http://www.soyuzagromash.info/documents Association of Producers of Agricultural Equipment and Machinery for Agro-Industrial Complex “Soyuzagromash” (2014)

From year to year, ploughland workload per one tractor increases. For the last 5 years, it has increased on the average by $23 \%$, thus resulting in premature deterioration of the equipment.

However, it is worthy of note that intensive development of agricultural manufacturing of the country means its technical and technological modernization, increasing labor productivity and resource saving. When the government started to implement the State Program on developing agricultural industry and controlling markets of agricultural products, raw materials and food products in 2008-2012, the agricultural organizations have demonstrated a tendency of decrease in reduction of fleet of tractors and grain harvesters. According to the preliminary data of the Russian Statistics Committee in 2012, the real re-equipment of the fleet was as follows: fleet of tractors $-3.4 \%$, fleet of grain harvesters and forage harvesters $-4.8 \%$.

According to the departmental accounts over a period of time 2008-2012, agricultural manufacturers purchased in fact 100.3 thousand tractors (57\% according to the plan), 35.2 thousand (64\%) grain harvesters and 10.1 thousand (59\%) forage harvesters. The share of tractors purchased during the complete period of implementing the State Program is $21 \%$ of their availability by agricultural manufacturers (477.2 thousand units), grain harvesters $-28 \%$ (126.8 thousand units) (National Report, 2013). 
Table 2. Availability of tractors and combines at Russian agricultural organizations

\begin{tabular}{|c|c|c|c|c|c|c|c|c|c|c|c|c|c|}
\hline & 1970 & 1980 & 1990 & 1995 & 2000 & 2005 & 2006 & 2007 & 2008 & 2009 & 2010 & 2011 & 2012 \\
\hline $\begin{array}{l}\text { Availability of } \\
\text { tractors per } 1000 \text { ha } \\
\text { of ploughland, pieces }\end{array}$ & 7.8 & 10.1 & 10.6 & 9.3 & 7.4 & 5.5 & 5.3 & 5 & 5 & 4 & 4 & 4 & 4 \\
\hline $\begin{array}{l}\text { Workload per one } \\
\text { tractor, ha }\end{array}$ & 129 & 99 & 95 & 108 & 135 & 181 & 187 & 197 & 210 & 226 & 236 & 247 & 258 \\
\hline \multicolumn{14}{|l|}{$\begin{array}{l}\text { Availability of } \\
\text { equipment per } 1000 \\
\text { ha of crops } \\
\text { (plantings) of } \\
\text { corresponding crop, } \\
\text { pieces: }\end{array}$} \\
\hline \multicolumn{14}{|l|}{ Combines: } \\
\hline Grain harvesters & 5.3 & 6.0 & 6.6 & 5.8 & 5.1 & 3.9 & 3.7 & 3 & 3 & 3 & 3 & 3 & 3 \\
\hline Corn combines & 25.0 & 23.9 & 12.4 & 14.8 & 8.3 & 4.7 & 2.9 & 2 & 1 & 1 & 1 & 1 & 1 \\
\hline Potato harvesters & 10.6 & 21.3 & 24.5 & 55.9 & 45.7 & 32.3 & 28.1 & 25 & 23 & 18 & 16 & 16 & 16 \\
\hline Flax combines & 8.7 & 21.6 & 21.8 & 34.4 & 32.2 & 21.6 & 21.0 & 21 & 19 & 18 & 24 & 18 & 16 \\
\hline $\begin{array}{l}\text { Beet harvesters } \\
\text { (without haulm } \\
\text { gatherers) }\end{array}$ & 16.7 & 18.6 & 16.5 & 18.2 & 16.1 & 10.8 & 7.6 & 6 & 6 & 5 & 4 & 3 & 3 \\
\hline \multicolumn{14}{|l|}{$\begin{array}{l}\text { Availability of crops } \\
\text { (plantings) of } \\
\text { corresponding crop, } \\
\text { ha: }\end{array}$} \\
\hline \multicolumn{14}{|l|}{ Per one combine: } \\
\hline Grain harvester & 189 & 167 & 152 & 173 & 198 & 253 & 270 & 291 & 317 & 344 & 327 & 354 & 369 \\
\hline Corn combine & 40 & 42 & 80 & 68 & 120 & 215 & 339 & 629 & 846 & 731 & 817 & 1115 & 1517 \\
\hline Potato harvester & 95 & 47 & 41 & 18 & 22 & 31 & 36 & 40 & 43 & 55 & 62 & 61 & 64 \\
\hline Flax combine & 115 & 46 & 46 & 29 & 31 & 46 & 48 & 47 & 54 & 56 & 42 & 54 & 64 \\
\hline $\begin{array}{l}\text { Per one beet } \\
\text { harvester (without } \\
\text { haulm gatherers) }\end{array}$ & 60 & 54 & 61 & 55 & 62 & 93 & 131 & 165 & 156 & 184 & 278 & 344 & 327 \\
\hline
\end{tabular}

Source: compiled by the authors according to the data provided by Dzotsenidze, Ipatov (2008), Didmanidze, Yesenovsky-Lashkov, Pilschikov (2005), http://www.soyuzagromash.info/documents Association of Producers of Agricultural Equipment and Machinery for Agro-Industrial Complex “Soyuzagromash” (2014)

The situation with demand is worsened by depressive economic condition of the agrarians due to low profitability of agricultural industry as well as low level of salaries thus making it impossible to satisfy present requirements for agricultural equipment to the full extent.

In this context, they try to activate the demand for the equipment in the country developing credit culture, stimulating leasing relations, which are introduced vigorously; but high risks of agrarians' activity make this process stagnant. The manufacturers themselves can help the agrarians by offering fairly priced equipment even for livestock farming - with which we have problems today (absence of acceptable product slate) - as a factor of diversification of risks due to adverse weather conditions as well as agrarians' paying capacity reduction.

In such difficult conditions for agrarians, the price factor determines demand. However, growing of associations in this branch, increasing administration as well as expenditure on it predetermined cartel prices, i.e. overstated reflecting largely losses of the customers and budget expenses. 
Price elasticity is high, because according to the Krugman's theory elasticity falls in the conditions of expansion in consumption and vigorous struggle for the customer between the manufacturers; and our agrarians' ability to consume especially at the current crisis period on the contrary decreases; hence they are not attractive target audience to be worth struggling for by the manufacturers. That is why the foreign manufacturers prefer to concentrate their attention on the markets of other countries, with their representative offices in our country only as one of the elements of diversification; and domestic manufacturers prefer to wait for terms that are more favorable to sell their products. On this account, it becomes a sorrowful regularity, most of investments are allocated to the warehouse development that is rather unsound under present-day conditions. Warehouses are necessary only in the conditions of high use value of commodities and following hereof steady consumption forecasts, which are absent today (Golovina, 2009; Morozova, 2006).

The situation with the manufacturers is worsened by disastrous wear of main recourses on the level of $80-100 \%$; rate of re-equipment here is not more than $3 \%$ overall in the country. Production facilities make it possible to manufacture much more agricultural equipment than agrarians can purchase not allowing the manufacturers to fulfil their potential integrally. Workload of capacity is about $15 \%$. In terms of the current crisis, this index declines drastically.

Domestic manufacturers of agricultural equipment due to insufficient competitive advantages of the equipment in comparison with foreign manufacturers use many districts' assignment to specific manufacturers - areas of responsibility at Agromashholding. Nevertheless, the market becomes more and more filled with the imported equipment. Key elements of their success on our market are high quality of equipment, available efficient service, prices not inflated due to speculations at stock market.

At the present stage, we could single out the following foreign manufacturers.

China. It offers latest patterns of outdated imported analogues. Engineering performance standard of domestic enterprises with few exceptions is essentially lower than that of the Chinese ones built during the last twenty-thirty years. Specific character of their offer is mini agricultural equipment, since due to their methods of copying, their technical potential is not sufficient to create powerful patterns. Today Kverneland Group is one of the most active participants of our market due to their sales and marketing office operating in Moscow.

The USA. US John Deere Company is especially very popular even when offering equipment at an overvalued price, since they supply the equipment of medium and super power, and for our country, such manufacturing is rather problematic. They have their representative offices in Kazakhstan, Ukraine, so they essentially restrict the Russian export supplies to these countries. Their tasks include, at first, to arrange equipment sales by means of distributive system Rosagroleasing, then to organize self-sufficient leasing for agrarians. Nowadays the US companies do not have the financial partner on the Russian market; American leasing organizations do not consider the Russian market to be attractive because of insufficiency of agrarians' financial resources. A government agency, Ex-Im Bank (Export-Import Bank of the United States) takes the entrepreneurial risks of particular companies that rather "carry out experiments" on our market, study its requirements. Their high prices demonstrate absence of long-term goals of developing our market. On the other part U.S. Agro Corporation holding controls $30 \%$ of the world agricultural equipment market, and plans to become more active in our country.

Germany. It is represented by the most striking instance, the CLAAS Company (it supplies twice as much the equipment than New Commonwealth does). Besides Kirovec-Landtehnik cooperates with German firm Krone; in terms of modern practice, such activities are not developed very well in Russia; they offer the following: engineering design for pig farms, assembling, computerization, they provide favorable warranty policy, training the specialists at the firm's expense.

Foreign manufacturers successfully introduced their products to our market due to infrastructural support concept created by them. Introducing the key components into the "culture" of our agricultural equipment market, they optimize the possibilities of our manufacturers.

Essential components of agricultural equipment market of industrialized countries are represented schematically in Figure 1.

The most difficult issue is to introduce commercial leasing, or more precisely, in fact, there is no commercial leasing. Overall agricultural equipment market is not exactly a promising one, and in modern terminology not innovative one. Domestic manufacturers do not have opportunities to produce innovative equipment, since the manufacturing environment as well as infrastructure of production are of very low level, they cannot be compared with foreign manufacturers. 


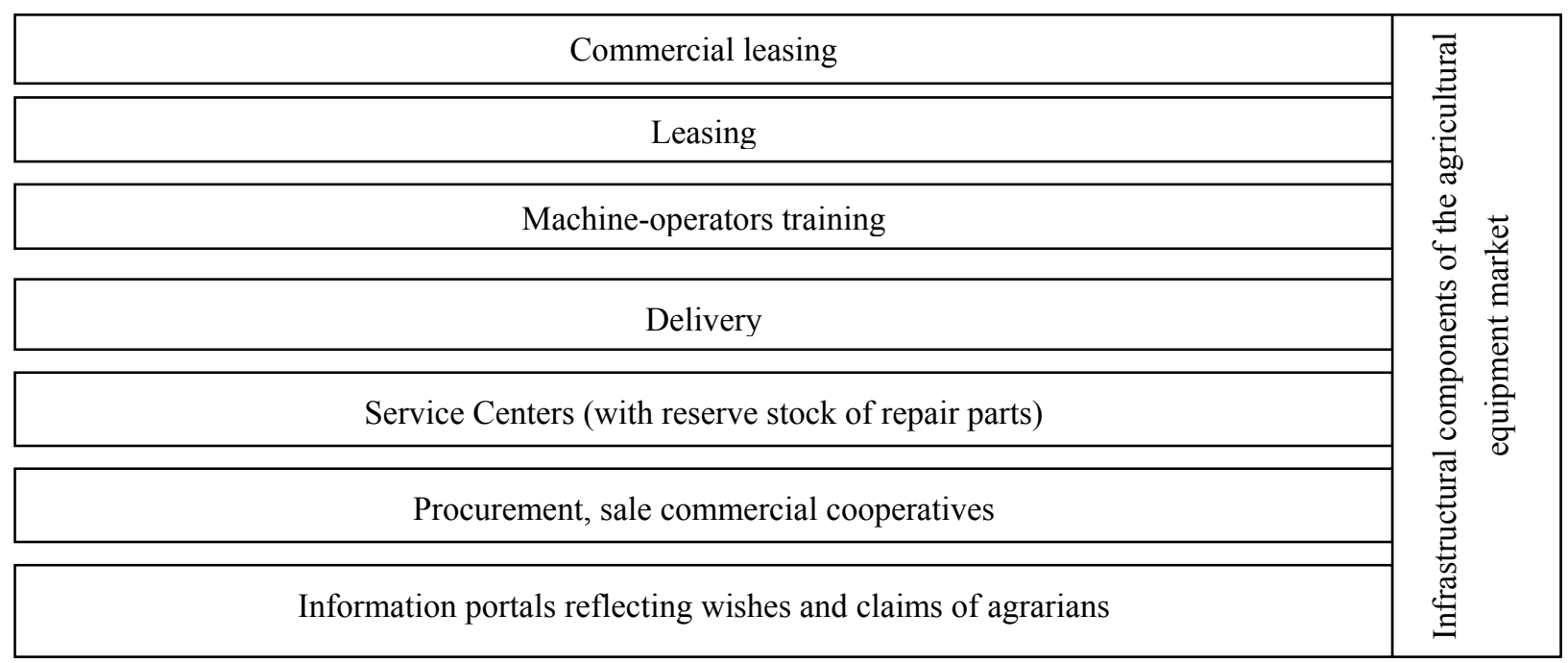

Figure 1. Essential components of the agricultural equipment market according to the foreign manufacturers

\section{State Policy on the Agricultural Equipment Market}

According to the carried out analysis we can draw a conclusion that the market in question has been critically monopolized; and negative tendencies cannot be resolved without interference of the state by means of changing its institutional forms. The consumers are deprived of the full-scale market choice of agricultural equipment; there are active price manipulations, information failure as well as non-equal terms of market behavior for different producers.

The government policy concerning the evaluation of enterprise functioning efficiency also worsens the situation. The ratings are made in accordance with the profit on goods sold at the enterprises.

Thus, after calculating the goods shipping in terms of money the agricultural equipment manufacturing enterprises have been ranged as follows:

1. Combine Plant Rostselmash Ltd. - grain harvesters and forage harvesters (Rostov-on-Don)

2. St. Petersburg Tractor Plant - tractors, ploughs, harrows (St. Petersburg).

3. Yelabuzhsky Automobile Plant - wheel-tire tractors (Tatarstan).

4. Krasnoyarsk Combine Plant - grain harvesters, threshing mechanisms (Krasnoyarsk).

5. Volgograd Tractor Plant - caterpillars (Volgograd).

6. Altay Tractor Plant Alttrak - caterpillars (Altaysky kray).

7. Company Klever - forage harvesters, reaping-machines for harvesting sunflower and corn, combine pickups (Rostov-on-Don).

8. Vladimir Motor Tractor Works - wheel-tire tractors (Vladimir).

9. BDM-Agro Company - disk headers (Krasnodar).

10. Siberian Agroindustrial House - seeding-machines, cultivators (Novosibirsk).

For this particular market the rating of the enterprises according to obtained aggregate profit on goods sold is ineffective; here it is necessary to have analysis and hence rating of the enterprises according to the sale of production units of every commodity to conceive the needs of agrarians.

Currently large owners represent the political interests.

The government uses the policy of protectionism concerning the agricultural equipment market. The government as well provides support; thus, in particular they decided to allocate 34 billion rubles to finance credits for machine-building enterprises. The government promotion of the industry will continue; it stimulates willingness to receive more budget money; but at the same time, it may result in tax evasion with changing the forms of profits appropriation.

Nowadays this position of the government cannot be considered justified for a number of reasons. In the first place, the agrarians' demand is not satisfied. In the second place, the market can be described in terms of 
dysfunctionality concerning the plentifulness of extra amount of products and at the same time shortage of them. The reason is that notwithstanding the support of the government, it is more profitable to manufacture and sell the equipment in Canada (where recently Rostselmash has purchased a company) than in our country.

In the third place, government's extreme measures applied starting January 2009 on domestic manufacturer protection do not result in profit improvement at enterprises, there is no growing activity of sale; to the contrary, there is growing amount of unsold output, i.e. elasticity to protectionist measures is missing making them useless; moreover it worsens the situation with agrarians.

Import is growing as well and as before not at the expense of progression of the market, but at the expense of decreasing amount of domestic manufacturers. Russia is not permitted to the foreign markets due to administrative obstacles.

Export is carried out mainly to Kazakhstan, Uzbekistan, Ukraine, but it does not resolve the problem of manufacturers' production distribution. Main kinds of products exported are combines, tractors, seeding machines.

At the same time, there is no developed service network, there are difficulties with currency conversion; there are complicated political relations with Ukraine; and foreign competitors invade the market of Kazakhstan. Foreign manufacturing enterprises apply indirect forms of export subsidy assistance providing the Kazakh party with opportunity to purchase the goods on favorable credit conditions. There is another actively used form, i.e. providing the Kazakh banks with credits by foreign commercial banks in order to refinance the import. The cost of credit is lower than when using traditional scheme ( $3 \%$ instead of $15 \%)$, that creates price advantage at the rate of $33 \%$.

Besides for this particular market seasonality is of current importance, hence, there are gaps in the flow of funds. The credits are necessary to level all mentioned above. The real situation is made worse with the following factors.

- Stereotypes concerning the necessity of repairing the equipment made by foreign manufacturers create difficulties while obtaining adequate economic evaluation. For that reason untested and outdated equipment, which is in need of constant and expensive repair, very often is imported to the Russian Federation.

- Lack of information on specific character of technical support for the equipment purchased. Beyond the warranty period agrarians often experience difficulties when buying essential spare parts without direct access to the market, hence resulting in non-scheduled costs.

Arrears to budget, financial and personnel problems, market imbalance, i.e. existence of shortage of products and extra amount of them (extra amount of combines, tractors of medium power, shortage of equipment for animal production) reflect mainly general regularities of restricting business activity in the industry (Table 3,4$)$.

Table 3. Factors restricting business activity of organization (on average of total amount of key organizations)

\begin{tabular}{lc}
\hline \multicolumn{1}{c}{ Factors } & $\begin{array}{c}\text { On average of total amount of key } \\
\text { organizations }\end{array}$ \\
\hline $\begin{array}{l}\text { Lack of money resources, \% } \\
\text { Inadequate demand for the products of the organization within the }\end{array}$ & 35 \\
country, \% & 42 \\
Economic uncertainty, \% & 16 \\
Absence of proper equipment, \% & 30 \\
High competitiveness of foreign manufacturers, \% & 25 \\
Inadequate demand for the products of the organization outside the \\
country, \%
\end{tabular}

Source: compiled by the data of Ministry of Agricultural Industry of the Russian Federation (2014), Federal State Statistics Service (2014).

The situation is not improved in spite of the fact that according to the Russian Classification of Economic Activities (OKVED 29.3-29.32.9) the enterprises of the Russian machine building have been transferred from the $27^{\text {th }}$ to the $26^{\text {th }}$ class of professional risk. Rate of insurance tariff is reduced from 5.5 to $5 \%$. Due to optimization of insurance loading, an enterprise can decrease current payment to the statutory social insurance scheme by $40 \%$ (Sisman et. al., 2014). 
Table 4. Evaluation of key factors restricting business of organizations functioning in the sphere of mineral extraction, manufacturing activities, production and distribution of electric power, gas and water (in the current quarter; percentage of total amount of examined organizations).

\begin{tabular}{|c|c|c|c|c|c|c|c|c|c|c|c|c|c|c|}
\hline & \multicolumn{4}{|c|}{$2006-2009$} & \multicolumn{4}{|c|}{2010} & \multicolumn{4}{|c|}{2011} & \multicolumn{2}{|c|}{2012} \\
\hline & \multicolumn{2}{|c|}{ Min } & \multicolumn{2}{|c|}{ Max } & \multirow[t]{2}{*}{$\begin{array}{c}\mathrm{I} \\
\text { quarter }\end{array}$} & \multirow[t]{2}{*}{$\begin{array}{c}\text { II } \\
\text { quarter }\end{array}$} & \multirow[t]{2}{*}{$\begin{array}{c}\text { III } \\
\text { quarter }\end{array}$} & \multirow[t]{2}{*}{$\begin{array}{c}\text { IV } \\
\text { quarter }\end{array}$} & \multirow[t]{2}{*}{$\begin{array}{c}\mathrm{I} \\
\text { quarter }\end{array}$} & \multirow[t]{2}{*}{$\begin{array}{c}\text { II } \\
\text { quarter }\end{array}$} & \multirow[t]{2}{*}{$\begin{array}{c}\text { III } \\
\text { quarter }\end{array}$} & \multirow[t]{2}{*}{$\begin{array}{c}\text { IV } \\
\text { quarter }\end{array}$} & \multirow[t]{2}{*}{$\begin{array}{c}\mathrm{I} \\
\text { quarter }\end{array}$} & \multirow[t]{2}{*}{$\begin{array}{c}\text { II } \\
\text { quarter }\end{array}$} \\
\hline & Period & Value & Period & Value & & & & & & & & & & \\
\hline \multicolumn{15}{|l|}{$\begin{array}{c}\text { Mineral } \\
\text { extraction }\end{array}$} \\
\hline $\begin{array}{c}\text { Domestic } \\
\text { inadequate } \\
\text { demand }\end{array}$ & $\begin{array}{c}\text { II } \\
\text { quarter } \\
2008 \\
\end{array}$ & 25 & $\begin{array}{c}\text { IV } \\
\text { quarter } \\
2008 \\
\end{array}$ & 58 & 55 & 49 & 42 & 44 & 46 & 41 & 35 & 36 & 38 & 31 \\
\hline $\begin{array}{l}\text { High level of } \\
\text { taxation }\end{array}$ & $\begin{array}{c}\text { III } \\
\text { quarter } \\
2009\end{array}$ & 40 & $\begin{array}{c}\text { II } \\
\text { quarter } \\
2006\end{array}$ & 52 & 43 & 44 & 44 & 43 & 47 & 54 & 49 & 56 & 56 & 51 \\
\hline $\begin{array}{l}\text { High rate of } \\
\text { commercial } \\
\text { loan }\end{array}$ & $\begin{array}{c}\text { II } \\
\text { quarter } \\
2008 \\
\end{array}$ & 19 & $\begin{array}{c}\text { I } \\
\text { quarter } \\
2006 \\
\end{array}$ & 28 & 31 & 25 & 27 & 27 & 28 & 19 & 25 & 22 & 24 & 25 \\
\hline $\begin{array}{l}\text { Shortage of } \\
\text { financial } \\
\text { resources }\end{array}$ & $\begin{array}{c}\text { II } \\
\text { quarter } \\
2008\end{array}$ & 37 & $\begin{array}{c}\text { IV } \\
\text { quarter } \\
2008 \\
\end{array}$ & 57 & 55 & 47 & 43 & 51 & 46 & 45 & 43 & 43 & 40 & 39 \\
\hline $\begin{array}{l}\text { Shortage of } \\
\text { specialists }\end{array}$ & $\begin{array}{c}\text { IV } \\
\text { quarter } \\
2009 \\
\end{array}$ & 18 & $\begin{array}{c}\text { III } \\
\text { quarter } \\
2008 \\
\end{array}$ & 35 & 22 & 22 & 25 & 24 & 21 & 21 & 19 & 19 & 22 & 28 \\
\hline $\begin{array}{c}\text { Deterioration } \\
\text { and absence of } \\
\text { equipment }\end{array}$ & $\begin{array}{c}\text { II } \\
\text { quarter } \\
2009 \\
\end{array}$ & 31 & $\begin{array}{c}\text { II } \\
\text { quarter } \\
2007 \\
\end{array}$ & 41 & 31 & 36 & 38 & 36 & 36 & 36 & 35 & 40 & 43 & 43 \\
\hline \multicolumn{15}{|l|}{$\begin{array}{c}\text { Manufacturing } \\
\text { activities }\end{array}$} \\
\hline $\begin{array}{c}\text { Domestic } \\
\text { inadequate } \\
\text { demand }\end{array}$ & $\begin{array}{c}\text { III } \\
\text { quarter } \\
2008 \\
\end{array}$ & 36 & $\begin{array}{c}\text { IV } \\
\text { quarter } \\
2009 \\
\end{array}$ & 63 & 60 & 56 & 51 & 52 & 54 & 50 & 48 & 51 & 51 & 47 \\
\hline $\begin{array}{l}\text { High level of } \\
\text { taxation }\end{array}$ & $\begin{array}{c}\text { III } \\
\text { quarter } \\
2006\end{array}$ & 41 & $\begin{array}{c}\text { II } \\
\text { quarter } \\
2008\end{array}$ & 49 & 44 & 45 & 45 & 49 & 57 & 64 & 62 & 63 & 62 & 57 \\
\hline $\begin{array}{l}\text { High rate of } \\
\text { commercial } \\
\text { loan }\end{array}$ & $\begin{array}{c}\text { IV } \\
\text { quarter } \\
2006 \\
\end{array}$ & 20 & $\begin{array}{c}\text { IV } \\
\text { quarter } \\
2009 \\
\end{array}$ & 31 & 19 & 27 & 28 & 27 & 28 & 24 & 25 & 25 & 26 & 24 \\
\hline $\begin{array}{l}\text { Shortage of } \\
\text { financial } \\
\text { resources } \\
\end{array}$ & $\begin{array}{c}\text { III } \\
\text { quarter } \\
2008 \\
\end{array}$ & 36 & $\begin{array}{c}\text { IV } \\
\text { quarter } \\
2009 \\
\end{array}$ & 48 & 47 & 42 & 42 & 42 & 42 & 41 & 39 & 38 & 39 & 37 \\
\hline $\begin{array}{l}\text { Shortage of } \\
\text { specialists }\end{array}$ & $\begin{array}{c}\text { II } \\
\text { quarter } \\
2009 \\
\end{array}$ & 17 & $\begin{array}{c}\text { III } \\
\text { quarter } \\
2008 \\
\end{array}$ & 37 & 19 & 23 & 25 & 26 & 25 & 25 & 27 & 27 & 26 & 28 \\
\hline $\begin{array}{c}\text { Deterioration } \\
\text { and absence of } \\
\text { equipment }\end{array}$ & $\begin{array}{c}\mathrm{I} \\
\text { quarter } \\
2009 \\
\end{array}$ & 17 & $\begin{array}{c}\text { IV } \\
\text { quarter } \\
2006 \\
\end{array}$ & 27 & 19 & 19 & 19 & 20 & 20 & 20 & 20 & 21 & 21 & 20 \\
\hline \multicolumn{15}{|l|}{$\begin{array}{c}\text { Production } \\
\text { and } \\
\text { distribution of } \\
\text { electric power, } \\
\text { gas and water }\end{array}$} \\
\hline $\begin{array}{c}\text { Domestic } \\
\text { inadequate } \\
\text { demand } \\
\end{array}$ & $\begin{array}{c}\mathrm{I} \\
\text { quarter } \\
2009 \\
\end{array}$ & 17 & $\begin{array}{c}\text { II } \\
\text { quarter } \\
2006 \\
\end{array}$ & 34 & 29 & 21 & 20 & 19 & 16 & 14 & 12 & 11 & 14 & 12 \\
\hline $\begin{array}{l}\text { High level of } \\
\text { taxation }\end{array}$ & $\begin{array}{c}\text { II } \\
\text { quarter } \\
2008 \\
\end{array}$ & 15 & $\begin{array}{c}\text { I } \\
\text { quarter } \\
2006 \\
\end{array}$ & 48 & 31 & 20 & 21 & 25 & 34 & 53 & 50 & 43 & 39 & 44 \\
\hline $\begin{array}{l}\text { High rate of } \\
\text { commercial } \\
\text { loan }\end{array}$ & $\begin{array}{c}\text { II } \\
\text { quarter } \\
2007 \\
\end{array}$ & 6 & $\begin{array}{c}\text { IV } \\
\text { quarter } \\
2007 \\
\end{array}$ & 14 & 33 & 13 & 11 & 13 & 11 & 14 & 13 & 13 & 12 & 11 \\
\hline $\begin{array}{l}\text { Shortage of } \\
\text { financial } \\
\text { resources } \\
\end{array}$ & $\begin{array}{c}\text { I } \\
\text { quarter } \\
2007 \\
\end{array}$ & 36 & $\begin{array}{c}\text { III } \\
\text { quarter } \\
2009 \\
\end{array}$ & 57 & 51 & 58 & 61 & 64 & 65 & 63 & 61 & 61 & 59 & 61 \\
\hline $\begin{array}{l}\text { Shortage of } \\
\text { specialists }\end{array}$ & $\begin{array}{c}\text { IV } \\
\text { quarter } \\
2009 \\
\end{array}$ & 12 & $\begin{array}{c}\text { III } \\
\text { quarter } \\
2008 \\
\end{array}$ & 32 & 15 & 14 & 16 & 16 & 19 & 15 & 11 & 13 & 11 & 12 \\
\hline $\begin{array}{c}\text { Deterioration } \\
\text { and absence of } \\
\text { equipment }\end{array}$ & $\begin{array}{c}\text { IV } \\
\text { quarter } \\
2006\end{array}$ & 16 & $\begin{array}{c}\text { I } \\
\text { quarter } \\
2009\end{array}$ & 46 & 33 & 60 & 65 & 65 & 59 & 47 & 45 & 44 & 50 & 58 \\
\hline
\end{tabular}


There are no foreign investments into this industry, and it is too expensive for enterprises to use investment fund because of short term. However, the Ministry of Finance of the Russian Federation acknowledged the opportunity of applying zero rate of value added tax by the Russian exporting companies.

On the whole, market positioning of the Russian manufacturers is not distinguished by high correlation with the interests of consumers as well as opportunities of further market development.

\section{Conclusions}

Lately the Russian society has faced serious problems, connected directly with the retrogression of agricultural industry development resulting in necessity of establishing and upgrading the manufacturing of modern equipment with high quality indices; that, undoubtedly, are of strategic significance for domestic economy.

Modern Russian market of agricultural equipment can be considered dysfunctional, since there is vast area of illegal actions taken by subjects of offence. We revealed the main problems of the agricultural equipment market violating functional relations of system level within the efficient entrepreneurial business, i.e. illegal seizure; growing amount of organizations with short term of operating (fly-by-night companies) stimulating illegal ways of selling technical equipment; dumping; growing amount of tax offences (Vellend et al., 2008).

According to the analysis of the position of different participants of agricultural equipment market, there are the following problems: mismatching between demand and supply of this market on the structural level; polarity of positions of the key participants; absence of coordinated interests both among the manufacturers, and among the manufacturers and consumers; domestic manufacturers' market relations infrastructure is developed weaker than infrastructure of the foreign ones; so the actions of the latter are more effective not only at present, but also in the future. Infrastructure of agricultural equipment manufacturing, which is to our opinion of current significance, can be represented schematically as follows (Figure 2).

\begin{tabular}{|c|c|}
\hline Provision of innovative projects & \multirow{7}{*}{ 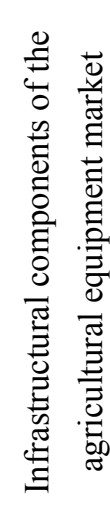 } \\
\hline Provision of labor resources & \\
\hline Provision of financial resources & \\
\hline Sales & \\
\hline Provision of equipment and technology & \\
\hline Representing the interests of the entrepreneurs in the politics & \\
\hline Informational support concerning the market requirements & \\
\hline
\end{tabular}

Figure 2. Components of current infrastructure of manufacturing the agricultural equipment

The world faces the forthcoming food problems, therefore in the Russian Federation agricultural industry improvement, and modern equipment manufacturing with high quality indices are of strategic importance and necessity at this very moment. At the same time, the study has demonstrated that system violations of market functionality lead to the ability of domestic manufacturers to pursue only short-term goals of developing as well as tendency to get "quick" profit; thus, it undermines their competitiveness and creates no favorable and strategic opportunities.

\section{References}

Association of Producers of Agricultural Equipment and Machinery for Agro-Industrial Complex Soyuzagromash. (2014). Retrieved August 12, 2014, from http://www.soyuzagromash.info/documents/

Didmanidze, O. N., Yesenovsky-Lashkov, Yu. K., \& Pilschikov, V. L. (2005). Specialized Carrying Equipment of Automobiles for Agricultural Industry: Textbook (p. 200). Moscow: Publishing House TRIADA.

Dzotsenidze, T. D., \& Ipatov, A. A. (2008). Creating New Means of Transport Infrastructure Development. Problems and Solutions (p. 272). Moscow: Publishing House Metallurgizdat. 
Federal State Statistics Service of the Russian Federation. (2014). Retrieved August 12, 2014, from http://www.gks.ru/

Frolov, D. P. (2008). Methodological institutionalism: New insight into evolution of economic science. Voprosy Economiki, 11(Issues of Economics), 90-101.

Golovina, T. A. (2009). Management of integrating managerial analysis methods from abroad to evaluate efficiency of assortment policy. Management in Russia and Abroad, 1, 22-32.

Ministry of Agricultural Industry of the Russian Federation. (2014). Retrieved August 12, 2014, from http://www.mcx.ru/

Morozova, I. A. (2006). Issue of improving competitiveness of Russia's transport system and its integration into international transport system. Izvestiya of VolgGTU (News of Volgograd State Technical University). Series "Current issues of reforming Russian economics (theory, practice, perspective)": Collection of scientific articles, Volgograd State Technical University, 6(11), 73-77.

Morozova, I. A., \& Litvinova, T. N. (2013). Major aspects of forecasting entrepreneurial business on the agricultural equipment market. Audit and Financial Analysis, 3, 404-408.

National Report. (2013). On 2012 Progress and Implementation of State Program on Developing the Agricultural Industry and Controlling Markets of Agricultural Products, Raw Materials and Food Products in 2008-2012. Moscow, Russia. Retrieved August 12, 2014, from http://www.mcx.ru/documents/file_ document/show/23818..htm

Rodrigues, A. S. L., \& Brooks, T. M. (2007). Shortcuts for Biodiversity Conservation Planning: The Effectiveness of Surrogates. Annual Review of Ecology, Evolution, and Systematics, 38, 713-737. http://dx.doi.org/10.1146/annurev.ecolsys.38.091206.095737

Sisman, C. B., Gezer, E., \& Kurc., H. C. (2014). Effects of Rice Husk on the Lightweight Concrete Properties Produced by Natural Zeolite for Agricultural Buildings. Asian Journal of Applied Sciences, 2(2), 158-162.

Snelder, T. H., Pella, H., Wasson, J. G., \& Lamouroux, N. (2008). Definition Procedures Have Little Effect on Performance of Environmental Classifications of Streams and Rivers. Environmental Management, 42, 771-788. http://dx.doi.org/10.1007/s00267-008-9188-1

Snelder, T., Lehmann, A., Lamouroux, N., Leathwick, J., \& Allenbach, K. (2009). Strong Influence of Variable Treatment on the Performance of Numerically Defined Ecological Regions. Environmental Management, 44, 658-670. http://dx.doi.org/10.1007/s00267-009-9352-2

Vellend, M., Bjorkman, M., \& Mcconchie, A. (2008). Environmentally biased fragmentation of oak savanna habitat on southeastern Vancouver Island, Canada. Biological Conservation, 1410, 2576-2584. http://dx.doi.org/10.1016/j.biocon.2008.07.019

\section{Copyrights}

Copyright for this article is retained by the author(s), with first publication rights granted to the journal.

This is an open-access article distributed under the terms and conditions of the Creative Commons Attribution license (http://creativecommons.org/licenses/by/3.0/). 